\title{
MEMOIRS
}

\author{
REGINALD EDWARD UNDERWOOD, M.B.E.
}

REgINALD EDWARD UNDER WOOD died on 4 June 1971 at the age of 85 years having retired some twenty years earlier from full-time employment. He commenced his insurance career as long ago as 1903 with the Guardian Assurance Company, and subsequently accepted an appointment with the Clerical, Medical and General Life Assurance Society from 1907 until 1912. For the following thirteen years covering the period of the First World War he was in the employment of the Commercial Union Assurance Company, qualifying as a Fcllow of the Institute in 1919. During the war he served as a 2 nd Lieutenant on special duties and on 3 June 1919 was awarded the M.B.E. in the Special List 'for valuable services rendered during the war'.

In 1925 he accepted a new challenge, becoming the first actuary in full-time service of a friendly society - the 'Liverpool Victoria'. For several years in the Institute tables of Occupations of Fellows he was shown as the only one so serving. He rendered 26 years service as Actuary of the 'Liverpool Victoria' spanning the Second World War and was responsible for the introduction and development of ordinary branch life assurance tables and for the reconstruction of the Society's pension schemes. It was his experience in this latter field which led him to submit a paper to the Institute for discussion in 1932 entitled "A "Money Purchase" Pension Scheme' (J.I.A. 1933, 64, 13).

He was always interested in education and in addition to service as a lecturer on life assurance and actuarial science in the City of London he wrote two text-books, The Student's Book of Life Assurance, published in 1924, particularly for the examinations for the Chartered Insurance Institute and Elements of Actuarial Science which was intended, perhaps somewhat surprisingly in these days, to cover part of the syllabus of the examinations of the Institute of Chartered Accountants. He was for many years a member of the Examiners Committee of the Chartered Insurance Institute in which he continued to take an interest over the years. Since his retirement from full-time business he had been a consultant with Lane, Clark \& Peacock, to which firm he transferred his incidental consulting practice mostly, but not exclusively, among friendly societies. The writer particularly remembers his attempts to get certain of the funds of the old London General Omnibus Company on to a sound footing and recollects the submission of nineteen reconstruction schemes. Underwood once told him that it was mostly the operation of a high lapse rate spread over the period of the successive reconstructions which enabled the funds eventually to become solvent again!

In 1925 he joined the Denarius Club, a dining club formed by actuaries engaged in industrial life assurance to continue discussions of the problems posed by the 1923 Act in more convivial surroundings. He served as Secretary of the Club and subsequently as President and continued to take a keen interest in its affairs, being a guest of honour at the December 1970 meeting. He was also a founder-member of the Fellowship Club. He was a kindly man, not easily ruffled and one who took a keen interest in the training and well-being of his younger colleagues.

He married Mabel Constance Saunders in 1910 who predeceased him, but he leaves a daughter, grandchildren and great grandchildren who were a comfort and lively interest to him in later years. He will be remembered as a competent actuary of great humanity and generosity of spirit.

H. F. FISHER

\section{HENRY O'BRIEN}

HENRY O'BRIEN died at Welwyn Garden City on 22 October 1971 at the age of 77 . He was born in 1894 and educated at Owen's School, Islington. On leaving school he spent a year or two on consultancy work under T. G. Ackland. At the age of 20 he entered the Life Department of the Royal Exchange Assurance (now the Guardian Royal Exchange Assurance) but the 
First World War was in progress and within six months he joined the Army. He received a commission in the Buffs and saw service in Mesopotamia.

On returning to civilian life he speedily completed the actuarial examinations, becoming a Fellow of the Institute in 1922 . He spent the whole of his subsequent career with the Royal Exchange Assurance, being made Assistant Manager of the important Trustee and Executor Department at the end of 1928. On the retirement of T. F. Anderson in November 1937, O'Brien succeeded him as Actuary to the Royal Exchange, a position which he held until he himself retired in the summer of 1954.

He served the Institute in many ways. Between 1927 and 1936 he worked successively as a Tutor, an Assistant Examiner and an Examiner. He became Assistant Editor of the Journal in 1933 and Editor in 1935; he remained as Editor for ten years. He was a member of Council for an unbroken period of eleven years from 1934 onwards, an Honorary Secretary from 1938 to 1940 and a Vice-President from 1940 to 1943.

Jointly with T. F. Anderson he presented to the Institute two papers dealing with experiments with actuarial functions and Fourier's Series (J.I.A. 1928, 59, 256 and J.I.A. 1936, 67, 31). These experiments extended over a decade, and entailed building a machine which would calculate the constants for the graduation formulae.

Henry O'Brien was at heart a dedicated mathematician who maintained the highest degree of intellectual integrity in everything that he handled. With this, he was endowed with an innate sense of humour. Like some of his favourite characters (for he was a great admirer of the Gilbert and Sullivan operas) he loved an argument, and would often adopt a perverse attitude in order to stimulate discussion.

Though perhaps not one to suffer fools gladly, he was truly the kindest of men and he was greatly respected by all who knew him.

O. D. CUMMING

\section{ARCHIBALD STEPHEN HOLNESS}

ON 24 FEBR U AR Y 1972 Archibald Stephen Holness died at the home of his daughter, Dr M. E. Symonds, in New Jersey, U.S.A. Born in 1884, he was educated at Owen's School, Islington, a school which the writer remembers as being notable for its tuition in mathematics. Here, in almost every year, Archie was top of his mathematics class. He also took a keen interest in Physical Training which was then being supervised by a pioneer in Swedish Gymnastics.

In 1903 he started his insurance career with the Pelican and British Empire Life Company, which was merged with the Phoenix in 1908. Like so many of his generation his career was broken by the First World War. He joined the Beds. \& Herts. Infantry at the beginning of 1916 and was sent to India where he was engaged on Administration with the Army Headquarters at Simla. He rejoined the staff of the Phoenix in 1920 and thereafter served his company with great distinction, becoming Joint Assistant Actuary in 1929 and Investment Manager in 1935. He retired from the Phoenix in 1945.

His services to the Institute, of which he became a Fellow in 1913, were no less meritorious and he was certainly one of those who have upheld the Baconian motto to the full. He served as an Examiner 1921-27, and on the Council 1934-38 and 1940-47. He was honoured by election as Vice-President for the years 1943-46 during which time he chaired several committees, in particular the Finance Committee 1943-44 and the General Purposes Committee 1944-46.

On his retirement from the Phoenix he placed his extensive financial experience at the disposal of the Finance Committee of London University and also of the City Parochial Charities.

Only those who did not know him well enough could fail to be surprised at the great enthusiasm with which he entered into other activities divorced from business. He was a keen tennis player, a good bridge player and an outstanding chess player. In this he was a mainstay of the Phoenix Chess Club, and it is reputed that, when out rambling with his fellow Assistant Actuary, the late T. P. Thompson, the two of them would play chess without board and pieces. 